\title{
Static and Dynamic Analysis Web Opening of Steel Beams
}

\author{
Hanady El-Dehemy \\ Civil Engineering Department, Higher Institute of Engineering and Technology, Kafr-elsheikh, Egypt \\ Email: hanadyeldehemy@yahoo.com
}

How to cite this paper: El-Dehemy, $\mathrm{H}$. (2017) Static and Dynamic Analysis Web Opening of Steel Beams. World Journal of Engineering and Technology, 5, 275-285. https://doi.org/10.4236/wjet.2017.52022

Received: January 13, 2017

Accepted: May 21, 2017

Published: May 24, 2017

Copyright $\odot 2017$ by author and Scientific Research Publishing Inc. This work is licensed under the Creative Commons Attribution International License (CC BY 4.0).

http://creativecommons.org/licenses/by/4.0/ (c) (i) Open Access

\begin{abstract}
According to the purpose of the opening and the structural designer, the shape of the web opening is decided. It is too easy to choose the shape of openings from regular shape whether it is circular or rectangular shape. The presence of openings in the web of steel beams decreases stiffness of the beam and introducing a larger deflection than in the steel web opening with solid opening. A steel beam with web opening is analyzed in this paper. ABAQUS software is using for analyzing nonlinear static and dynamic opening of steel beam with different position and supporting conditions.
\end{abstract}

\section{Keywords}

Web Openings, Steel Beam, ABAQUS Software, Nonlinear Static and Dynamic Analysis

\section{Introduction}

For Structural Engineer, the accountability not only in designing the safety and serviceability conditions of the structure but also considering the function of using it. While designing a power plant or a high rise building, the traditional system for this is a steel frame consists of beams and girders with solid webs. Any modification in services of the structure (by increasing the height of floor or adding air conditioning ducts) contributes to increase the commissioning which that is not acceptable, see Figure 1. In order to save time and money it is possible to use a steel beam with web opening directly at location. For most sites, replacement services of structure within the web through the opening. The presence of opening in web of steel beam changes the stress distribution and the behavior of collapse. In modern structures, the one of the most important consideration is the efficient design of beams girders with web opening. Various authors and standards, two approaches (Tee Section and Perforated Section) are 

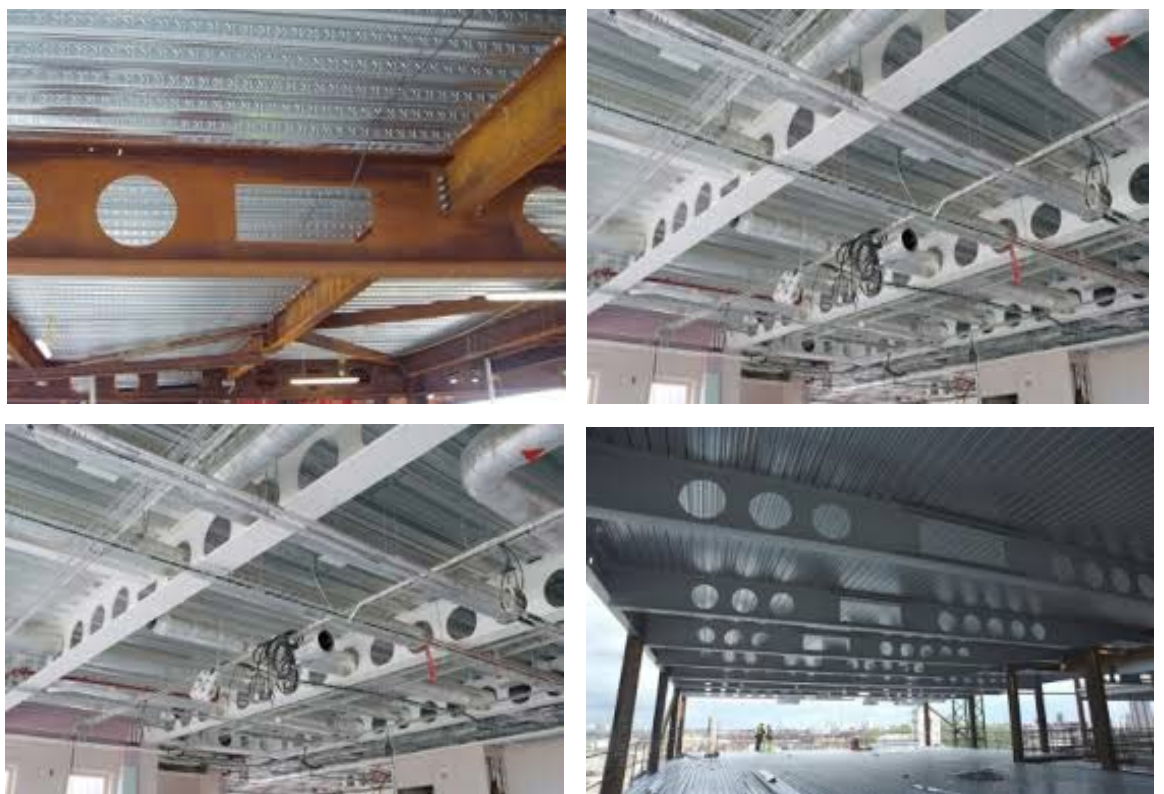

Figure 1. Web openings steel beam applications.

possible for the design of steel and composite beams with web openings has been indicated by Chung and Ko [1], Chung and Lawson [2], Lawson [3], Darwin [4], Redwood and Cho [5], Oehlers and Bradford [6]. To design these girders, plastic section analysis methods, are reported by Chung et al. [7]. Chung et al. [8] for steel beams and Chung and Lawson [2] for composite beams stated that services that require web openings up to $75 \%$ of the beam height are not uncommon. These openings could lead to a significant decrease of the beam load carrying capacity depending on the adopted openings shape, size and location. Circular and rectangular openings are frequently used with a possible adoption of stiffeners welded near the web openings to improve the beam load carrying capacity. A study about the buckling curve for lateral-torsional buckling resistance of castellated beams was developed by Lakusic et al. [9] considering an experimental and a numerical analysis based on finite elements models. According to the obtained results, the use of the buckling curved for welded beams [10]-[11], category in which castellated beams are included, instead of the buckling curve $\mathrm{c}$ for rolled sections, leads to a severe value for the reliability index target i.e. 3.8 associated to the structure class RC2. A numerical analysis of castellated beams considering two different procedures performed by Radic et al. [12] for the calculation of the elastic critical moment for lateral torsional buckling comparing FE results and Eurocode 3 procedures [10]-[11]. Other works can be cited concerning the web openings beams behavior. Basher et al. [13] investigated the effects of circular or square web openings on the ultimate strength of horizontally curved composite plate girders. Some numerical simulations in order to provide data for the development of a design model for the shear capacity of steel girders with web openings, with and without transverse stiffeners and opening reinforcements were performed by Hagen et al. [14] and Hagen and Larsen [15]. Lagaros et al. [16] studied an optimum design of 3D steel structures having per- 
forated I-section beams. Lian and Shanmugan [17] reported that on plate girders curved in plan containing centrally placed circular web openings, the observed failure mechanism in the tests was similar to that observed in plate girders without web openings, the only difference being the position of plastic hinges on the flange plates. Liu and Chung [18] presented a comprehensive finite element investigation on steel beams with web openings of various shapes and sizes. Finally, a finite element modeling of perforated composite beams with flexible shear connectors was developed by Wang and Chung [19]. For analysis and design of composite beams, a numerical model has been developed, in order to evaluate the structural behavior of perforated beams as well as the influence of web openings in the load carry capacity. The non-linear behavior of the concrete and steel has been taken into account. Thus, the concrete has been modeled with concrete damaged plasticity, CDP, included in the finite element software [20].

According to the above, for designing the steel and composite beams, the plastic analysis methods are using. The services that require for web openings up to $75 \%$ of the beam height are not commonly used. Circular and rectangular shapes are frequently used for web openings at locations. For castellated beams, the study of lateral torsional buckling uses the experimental and a numerical analysis with finite elements analysis. For others, studying the shear capacity of steel beams with web openings with and without transverse stiffeners and opening reinforcements were performed.

ABAQUS software provides a good analysis for designing various structural systems. ABAQUS model easily modeled a steel beam and steel beams with opening. A present study focuses on the analysis of deflection and stresses for steel beam with and without web opening by static and dynamic nonlinear analysis.

\section{Guide Lines for Web Openings}

The guide lines for web openings should be considered as follow: 1- The opening should be centrally placed in the web and eccentricity of the opening is avoided as far as possible. 2- For the supporting end conditions, the web opening should be away by at least twice the beam depth, D or $10 \%$ of the span, whichever is greater. 3- At the middle third of the span is the best location for the opening. 4Clear Spacing between the openings should not be less than beam depth; D. 5For shearing force where it has a lower value, is the best location of opening. 6The diameter of circular openings is $0.5 \mathrm{D}$. 7- Depth of rectangular openings should not be greater than $0.5 \mathrm{D}$ and the length not greater than $1.5 \mathrm{D}$ for un-stiffened openings. 8- The clear spacing between such openings should be at least equal the longer dimension of the opening. 9- Corners of rectangular openings should be rounded. 10- Point loads should not be applied at less than $\mathrm{D}$ from side of the adjacent opening.

There are three different steel web opening failure modei. eshear, bending and Vierendeel collapses. A change rate in the bending moment distribution (and the shear force) along the opening is responsible for the Vierendeel collapse mechanism in steel beams web openings [21]. The upper and lower "Tees" are 
resisting the increasing in the rate of the bending moment through their local bending strengths. At the perforated sections, the opening height controls the collapse of bending moment and shearing force, and the width of opening controls the vierendeel collapse mechanism which also depends on the local shear and moment resistance for the upper and lower. Three local actions introduced at the upper and lower "Tees" present in a perforated section subjected to global bending moment $\left(M_{o, S d}\right)$ and a shear force $\left(V_{o, S d}\right)$, see Figure 2 . These actions are: the axial force, $N_{T}$, due to the global bending moment $\left(M_{o, S d}\right)$, the shear force, $V_{T}$, due to the global shear force $\left(V_{o, S d}\right)$, and the bending moment $M_{T}$, that appears due to the shear force $\left(V_{o, S d}\right)$ transmitted along the opening length. The capacities for bending moment and shearing force can be easily generally calculated. Also any increasing the web opening height reduce the capacities for bending moment and shearing force.

\subsection{Finite Element Modeling}

A finite element model of steel beam type IPE 400 with $5.0 \mathrm{~m}$ span length and 25 $\mathrm{N} / \mathrm{m}^{2}$ uniform loads. The opening has a $2.0 \times 2.0 \mathrm{~m}$ dimension with a rectangular shape. The parametric studies on this model will be as different ends conditions (hinged or fixed ends), positions of the opening (at the middle span, at 1/4 of span length), and type of nonlinear analysis (static or dynamic). The dynamic analysis can conduct by using damping ratio 5\% and the load was applied for seven seconds on the model. The comparison between results in deflection and stresses.

\subsection{The Results}

\subsubsection{Nonlinear Static Analysis}

1) Fixed Case

In the next section the results of nonlinear analysis fixed end conditions for

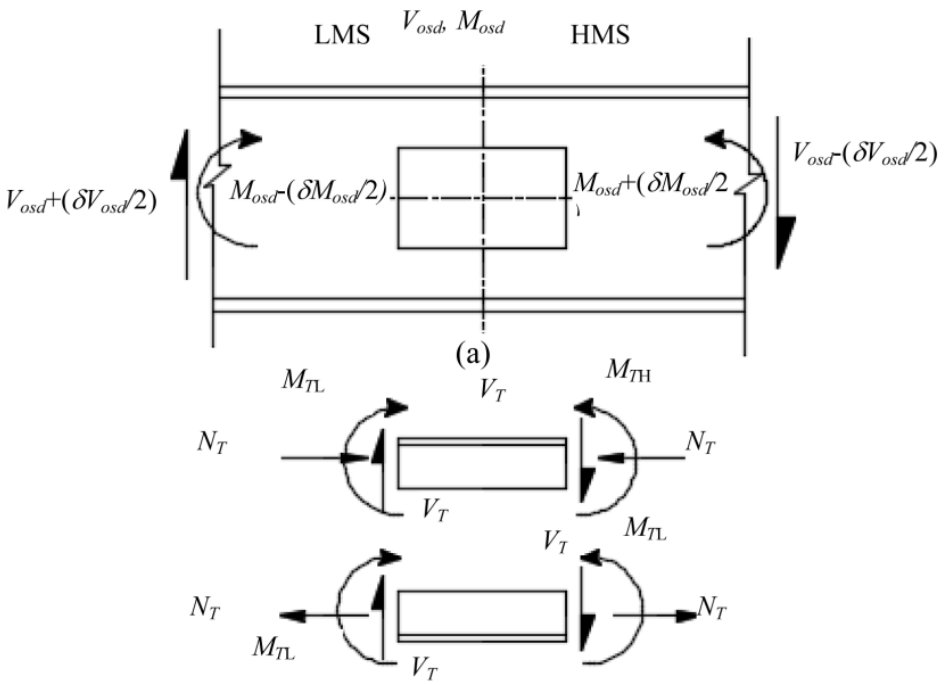

(b)

Figure 2. Force distribution in steel web opening. 
web opening is obtained. Figure 3 shows the deflection and stresses of steel beam without opening. Figure 4 shows the deflection and stresses of steel beam with one opening at middle span of beam. The deflection and stresses of steel beam with two openings at 1/4 of span length of beam shown in Figure 5.

\section{2) Hinged Case}

In the next section the results of nonlinear analysis hinged end condition for web opening is obtained. Figure 6 shows the deflection and stresses of steel beam without opening. Figure 7 shows the deflection and stresses of steel beam with one opening at middle span of beam. The deflection and stresses of steel beam with two openings at 1/4 of span length of beam shown in Figure 8.

\subsubsection{Nonlinear Dynamic Analysis}

\section{1) Fixed Case}

In the next section the results of nonlinear analysis fixed end condition for web opening is obtained. Figure 9 shows the deflection and stresses of steel beam without opening. Figure 10 shows the deflection and stresses of steel beam

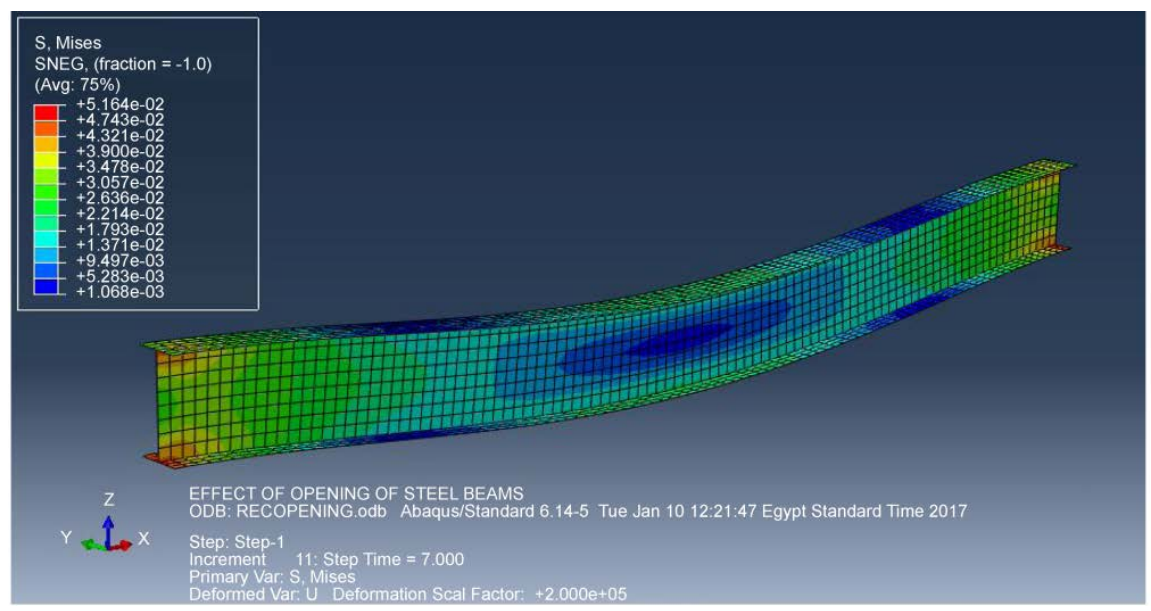

Figure 3. The deflection and stresses of steel beam without opening for nonlinear static fixed analysis.

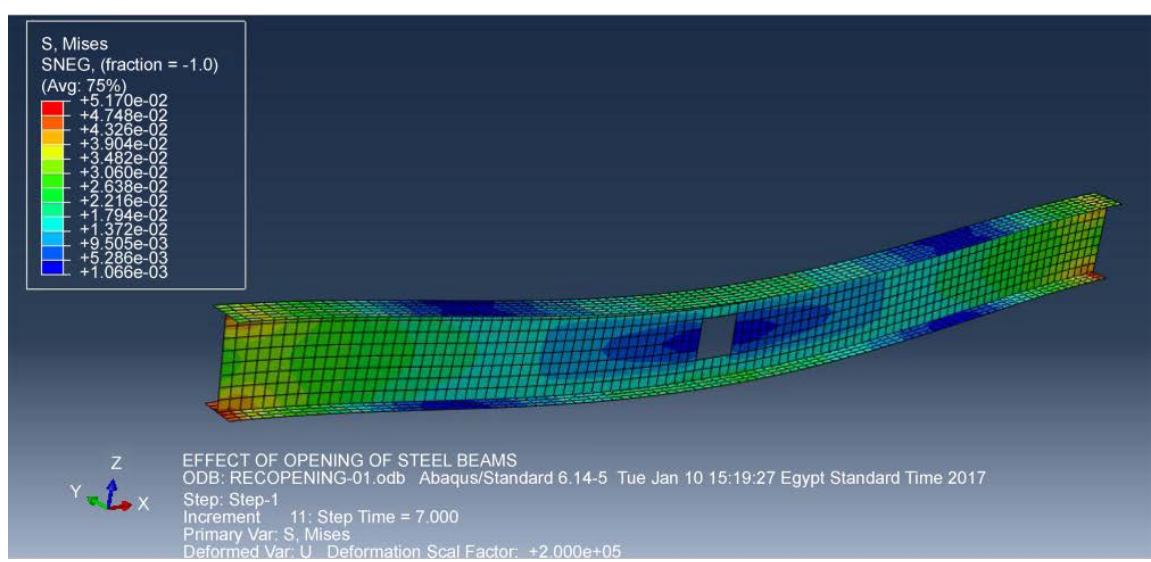

Figure 4. The deflection and stresses of steel beam with one opening for nonlinear static fixed analysis. 


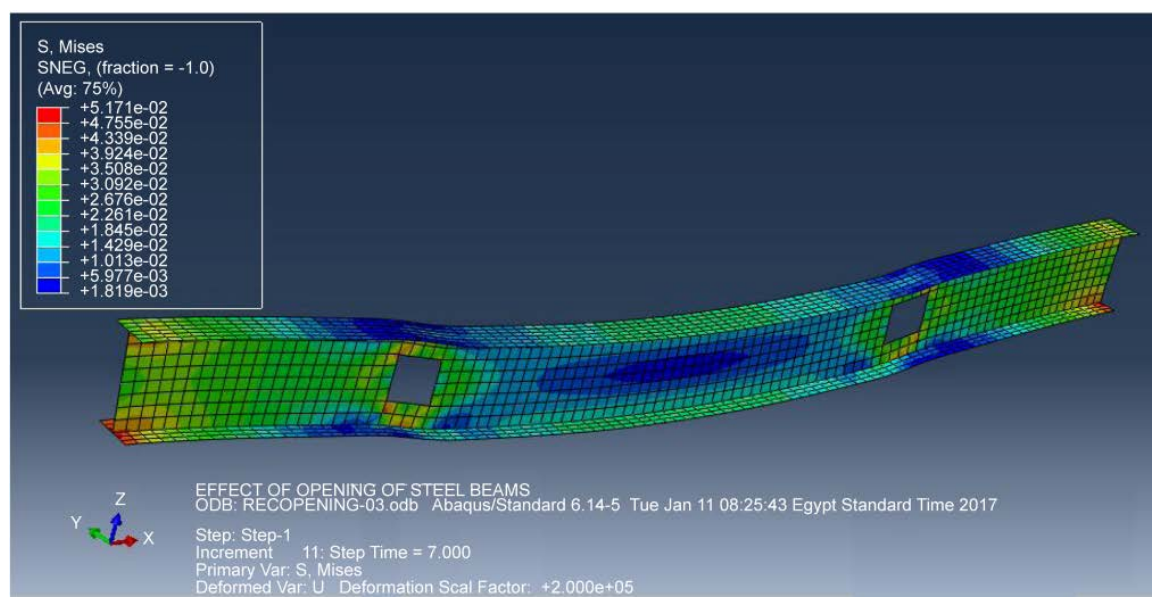

Figure 5. The deflection and stresses of steel beam with two openings for nonlinear static fixed analysis.

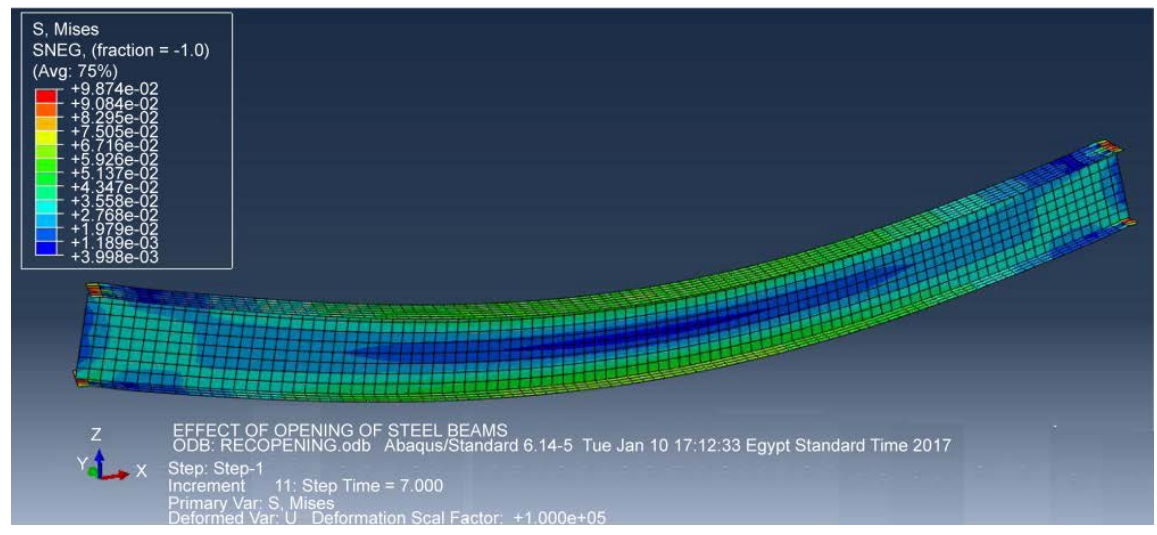

Figure 6. The deflection and stresses of steel beam without opening for nonlinear static hinged analysis.

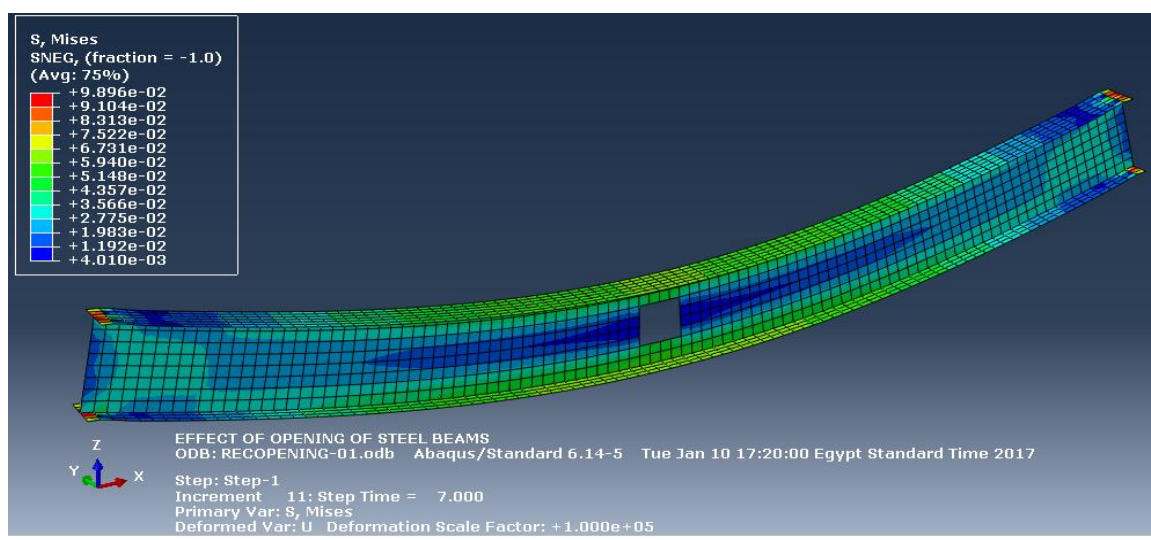

Figure 7. The deflection and stresses of steel beam with one opening for nonlinear static hinged analysis.

with one opening at middle span of beam. The deflection and stresses of steel beam with two openings at 1/4 of span length of beam shown in Figure 11.

2) Hinged Case

In the next section the results of nonlinear analysis hinged end condition for 


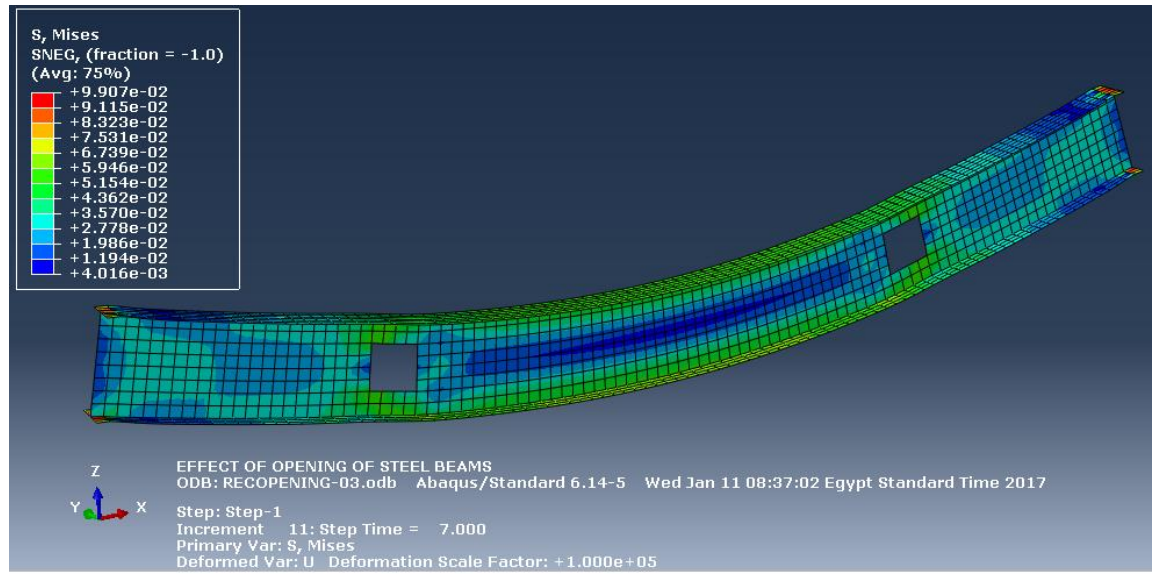

Figure 8. The deflection and stresses of steel beam with two openings for nonlinear static hinged analysis.

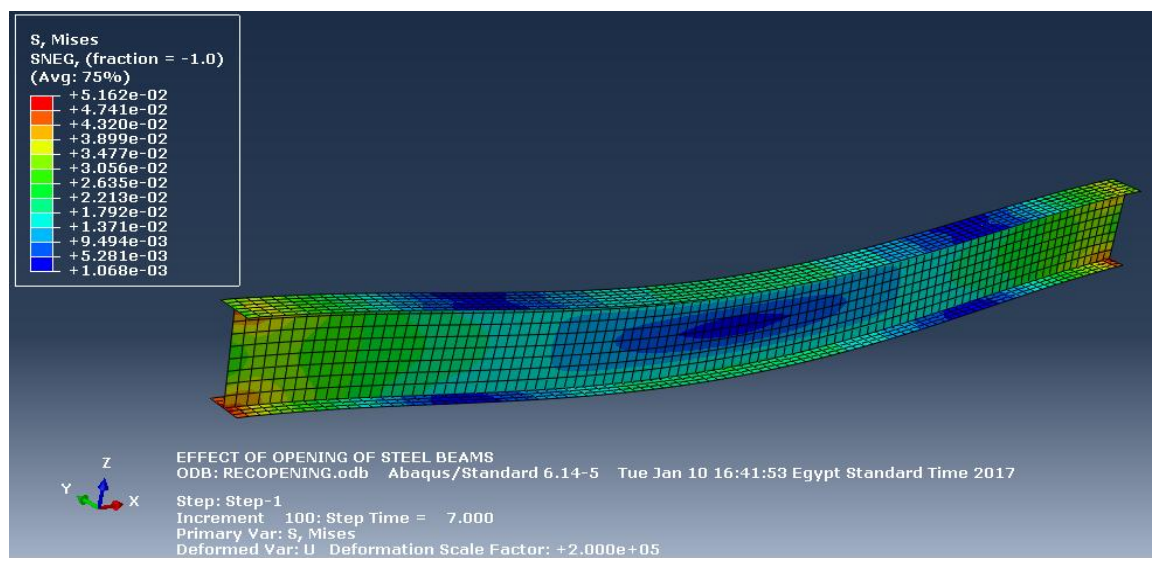

Figure 9. The deflection and stresses of steel beam without opening for nonlinear dynamic fixed analysis.

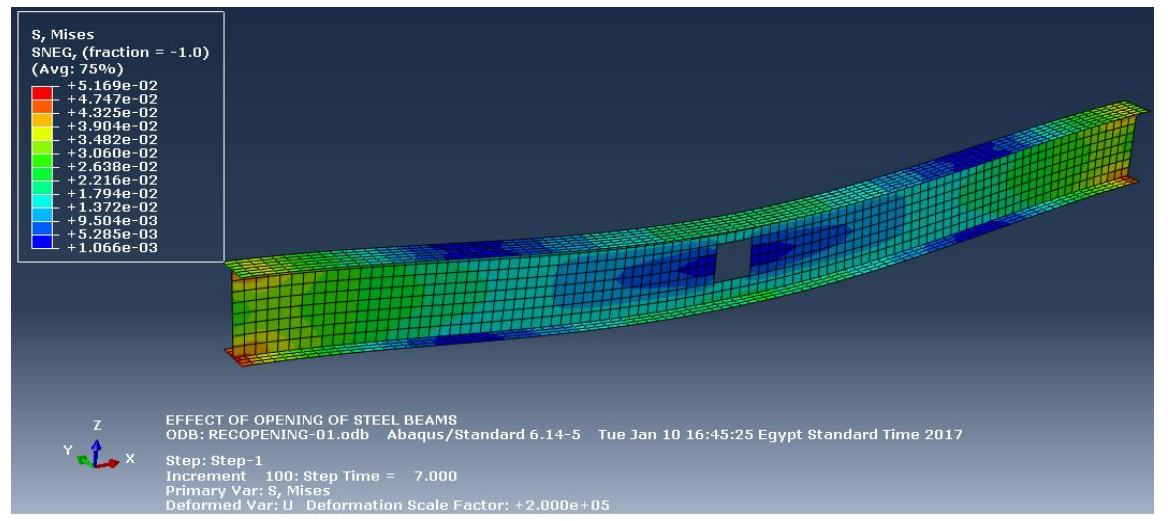

Figure 10. The deflection and stresses of steel beam with one opening for nonlinear dynamic fixed analysis.

web opening is obtained. Figure 12 shows the deflection and stresses of steel beam without opening. Figure 13 shows the deflection and stresses of steel beam with one opening at middle span of beam. The deflection and stresses of steel beam with two openings at 1/4 of span length of beam shown in Figure 14. 


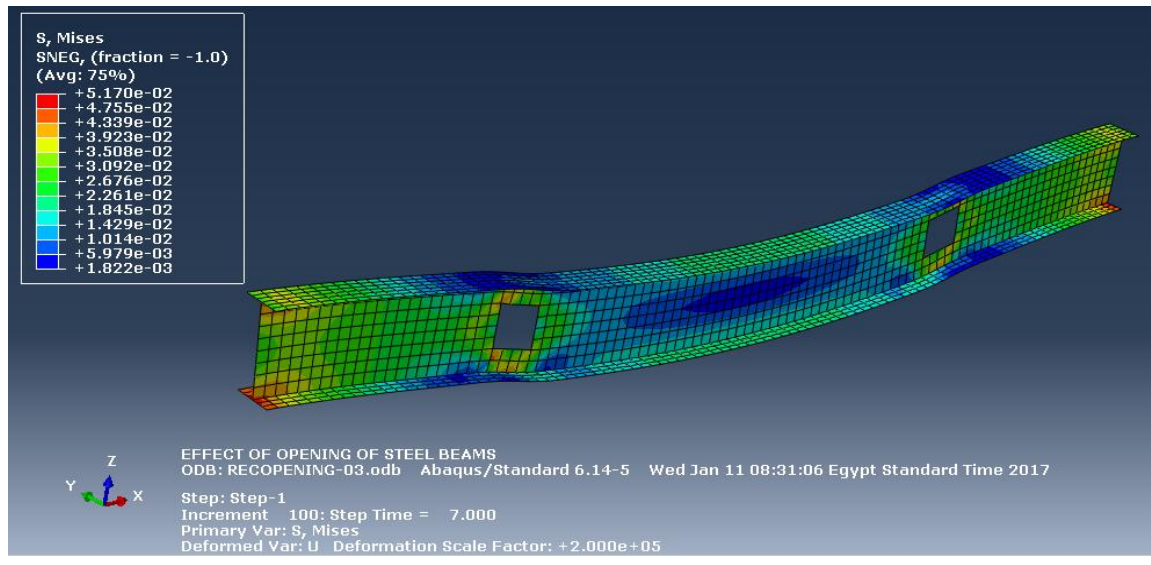

Figure 11. The deflection and stresses of steel beam with two openings for nonlinear dynamic fixed analysis.

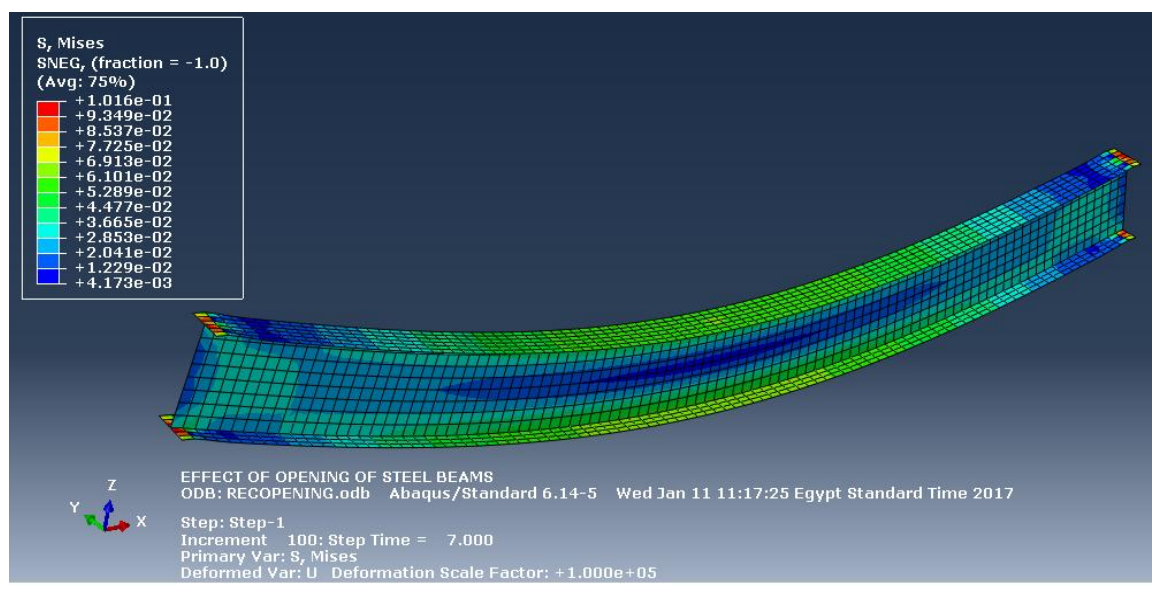

Figure 12. The deflection and stresses of steel beam without opening for nonlinear dynamic hinged analysis.

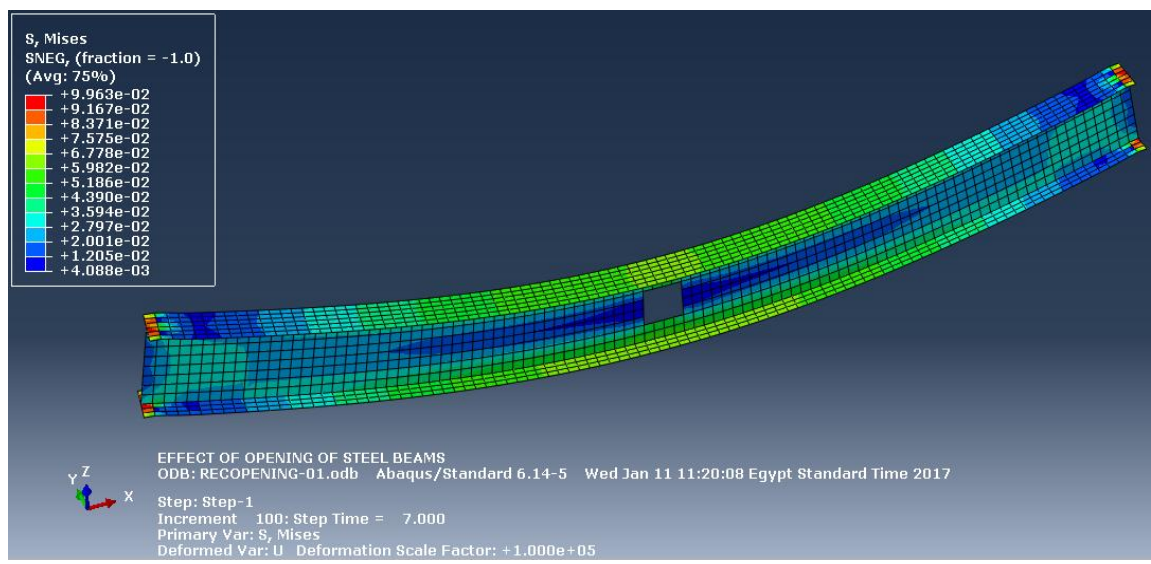

Figure 13. The deflection and stresses of steel beam with one opening for nonlinear dynamic hinged analysis.

Table 1 shows the results for nonlinear static and dynamic analysis, fixed and hinged end conditions, for web steel without opening, one opening at middle span and two openings at $1 / 4$ of span length of beam. 


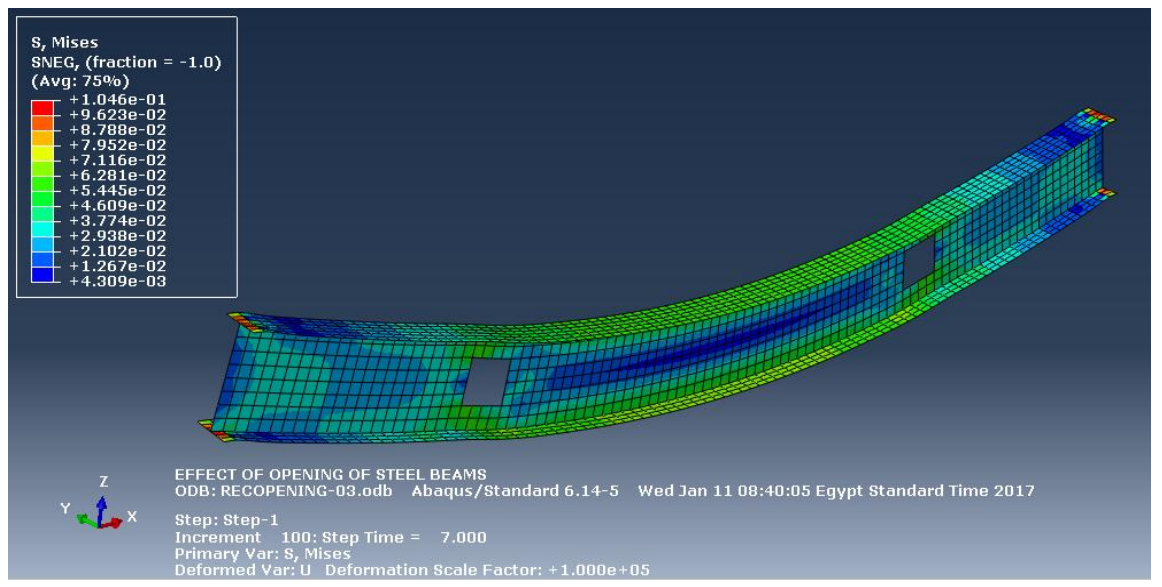

Figure 14. The deflection and stresses of steel beam with two openings for nonlinear dynamic hinged analysis.

Table 1. The results for nonlinear static and dynamic analysis.

\begin{tabular}{|c|c|c|}
\hline \multirow{3}{*}{ Case of web opening } & \multicolumn{2}{|c|}{ Type of analysis } \\
\hline & \multicolumn{2}{|c|}{ Nonlinear static fixed analysis } \\
\hline & Stress $\left(\mathrm{N} / \mathrm{mm}^{2}\right)$ & Deflection $(\mathrm{mm})$ \\
\hline Without opening & $1.068 \mathrm{E}-3$ & $-1.1109 \mathrm{E}-3$ \\
\hline With one opening & $1.066 \mathrm{E}-3$ & $-1.1158 \mathrm{E}-3$ \\
\hline \multirow[t]{3}{*}{ With two openings } & $1.819 \mathrm{E}-3$ & $-1.2383 \mathrm{E}-3$ \\
\hline & \multicolumn{2}{|c|}{ Nonlinear static hinged analysis } \\
\hline & Stress $\left(\mathrm{N} / \mathrm{mm}^{2}\right)$ & Deflection $(\mathrm{mm})$ \\
\hline Without opening & $3.99 \mathrm{E}-3$ & $-4.193 \mathrm{E}-3$ \\
\hline With one opening & $4.01 \mathrm{E}-3$ & $-4.2075 \mathrm{E}-3$ \\
\hline \multirow[t]{3}{*}{ With two openings } & $4.016 \mathrm{E}-3$ & $-4.3307 \mathrm{E}-3$ \\
\hline & \multicolumn{2}{|c|}{ Nonlinear dynamic fixed analysis } \\
\hline & Stress $\left(\mathrm{N} / \mathrm{mm}^{2}\right)$ & Deflection $(\mathrm{mm})$ \\
\hline Without opening & $1.068 \mathrm{E}-3$ & $-1.1103 \mathrm{E}-3$ \\
\hline With one opening & $1.066 \mathrm{E}-3$ & $-1.1156 \mathrm{E}-3$ \\
\hline \multirow[t]{3}{*}{ With two openings } & $1.822 \mathrm{E}-3$ & $-1.238 \mathrm{E}-3$ \\
\hline & \multicolumn{2}{|c|}{ Nonlinear dynamic hinged analysis } \\
\hline & Stress $\left(\mathrm{N} / \mathrm{mm}^{2}\right)$ & Deflection $(\mathrm{mm})$ \\
\hline Without opening & $4.173 \mathrm{E}-3$ & $-4.3127 \mathrm{E}-3$ \\
\hline With one opening & $4.088 \mathrm{E}-3$ & $-4.2303 \mathrm{E}-3$ \\
\hline With two openings & $4.309 \mathrm{E}-3$ & $-4.5744 \mathrm{E}-3$ \\
\hline
\end{tabular}

\section{Conclusions}

This paper presented an ABAQUS finite element models software to achieve the structural response of steel beams with web openings in terms of stress distributions, and deflection. The analysis carried out using geometric and material non- 
linearities. The achievement also concluded statically and dynamically analysis. The results obtained from above analysis are:

1) The value of deflection for a steel beam is increases as the number of opening is increases. Also the stresses for a steel beam are increases as the number of openings is increases.

2) For hinged end condition for web opening even if one opening or two openings the value of deflection has a higher value than the fixed end condition.

3) For dynamic analysis of web opening even if one opening or two openings the value of deflection and stresses have a higher value than static analysis.

4) The stresses have higher values near the opening in static and dynamic analysis.

5) According to the above results it's giving a close results to that observed from R. R. Jichkar et al. [22], including the dynamic effect on the steel beams; the ABAQUS software gives a good analysis model for steel beams with web opening.

For future work, experimental studies are needed to retrofit schemes to improve the local resistance of an element subjected to the large deformations that occur. In this study, one simple or fixed span supported beam with one cross section is used in the analysis, for different factors like partially fixed end case, continuous spans, large span length and many cross sections should be studied. Change the dynamic factor such as damping ratio or nonlinerities factor such as boundary conditions.

\section{References}

[1] Chung, K.F. and Ko, C.H. (2002) Harmonization on Practical Design of Steel and Composite Beams with Large Web Openings for Full Integration with Building Services. Proceedings of the Second Structural Engineering World Congress, Yokohama, 9-12 October 2002.

[2] Chung, K.F. and Lawson, R.M. (2001) Simplified Design of Composite Beams with Large Web Openings to Eurocode 4. Journal of Constructional Steel Research, 57, 135-163.

[3] Lawson, R.M. (1987) Design for Openings in the Webs of Composite Beams. CIRIA/Steel Construction Institute, CIRIA Special Publication and SCI Publication 068, Ascot.

[4] Darwin, D. (1990) Steel and Composite Beams with Web Openings. Steel Design Guide Series, Vol. 2, AISC-American Institute of Steel Construction, Chicago.

[5] Redwood, R.G. and Cho, S.H. (1993) Design of Steel and Composite Beams with Web Openings. Journal of Constructional Steel Research, 25, 23-41.

[6] Oehlers, D.J. and Bradford, M.A. (1995) Composite Steel and Concrete Structural Members: Fundamental Behavior. Kidlington, Oxford.

[7] Chung, K.F., Ko, C.H. and Wang, A.J. (2005) Design of Steel and Composite Beams with Web Openings-Verification Using Finite Element Method. Steel and Composite Structures, 5, 203-233. https://doi.org/10.12989/scs.2005.5.2_3.203

[8] Chung, K.F., Liu, T.C.H. and Ko, A.C.H. (2001) Investigation on Vierendeel Mechanism in Steel Beams with Circular Web Openings. Journal of Constructional Steel Research, 57, 467-490.

[9] Lakusic, V.T., Dzeba, I. and Androic, B. (2008) The Buckling Curve for LateralTorsional Buckling Resistance of Castellated Beams. Eurosteel-5th European Con- 
ference on Steel and Composite Structures, Graz, 3-5 September 2008, 1587-1592.

[10] CEN-European Committee for Standardization (1998) Eurocode 3: Design of Steel Structures, Part 1-1: General Rules and Rules for Buildings. ENV 1993-1-1: 1992/A2 Annex N, Brussels.

[11] CEN-European Committee for Standardization (1992) Eurocode 3: Design of Steel Structures, Part 1-1: General Rules and Rules for Buildings. EN 1993-1-1, Brussels, Belgium and Not ENV 1993-1-1, Brussels, Belgium.

[12] Radic, I., Markulak, D. and Varevac, D. (2008) Numerical Simulation of Lateral Stability. Eurosteel-5 th European Conference on Steel and Composite Structures, Graz, 3-5 September 2008, 1593-1598.

[13] Basher, M.A., Shanmugam, N.E. and Khalim, A.R. (2009) Web Openings in Horizontally Curved Composite Plate Girders. Journal of Constructional Steel Research, 65, 1694-1704.

[14] Hagen, N.C. and Larsen, P.K. (2009) Shear Capacity of Steel Plate Girders with Large Web Openings, Part II: Design Guidelines. Journal of Constructional Steel Research, 65, 151-158.

[15] Hagen, N.C. and Larsen, P.K. (2009) Shear Capacity of Steel Plate Girders with Large Web Openings, Part II: Design Guidelines. Journal of Constructional Steel Research, 65, 151-158.

[16] Lagaros, N.D., Psarras, L.D., Papadrakakis, M. and Panagiotou, G. (2008) Optimum Design of Steel Structures with Web Openings. Engineering Structures, 30, 25282537.

[17] Lian, V.T. and Shanmugan, N.E. (2003) Openings in Horizontally Curved Plate Girder Webs. Thin- Walled Structures, 41, 245-269.

[18] Liu, T.C.H. and Chung, K.F. (2003) Steel Beams with Large Web Openings of Various Shapes and Sizes: Finite Element Investigation. Journal of Constructional Steel Research, 59, 1159-1176.

[19] Wang, A.J. and Chung, K.F. (2008) Advanced Finite Element Modelling of Perforated Composite Beams with Flexible Shear Connectors. Engineering Structures, 30, 2724-2738.

[20] Tiago Miguel CameiraNeto (2014) Analysis and Design of Composite Beams with Web Openings. Department of Civil Engineering, Arquitecture and Georesources, Instituto Superior Técnico, Lisbon University, Av. Rovisco Pais, 1049-001 LisbonPortugal.

[21] Chung, K.F., Liu, T.C.H. and Ko, A.C.H. (2003) Steel Beams with Large Web Openings of Various Shapes and Sizes: An Empirical Design Method Using a Generalised Moment-Shear Interaction Curve. Journal of Constructional Steel Research, 59, 1177-1200.

[22] Jichkar, R.R., Arukia, N.S. and Pachpor, P.D. (2014) Analysis of Steel Beam with Web Openings Subjected to Buckling Load. Journal of Engineering Research and Applications, 4, 185-188. 
Submit or recommend next manuscript to SCIRP and we will provide best service for you:

Accepting pre-submission inquiries through Email, Facebook, LinkedIn, Twitter, etc. A wide selection of journals (inclusive of 9 subjects, more than 200 journals)

Providing 24-hour high-quality service

User-friendly online submission system

Fair and swift peer-review system

Efficient typesetting and proofreading procedure

Display of the result of downloads and visits, as well as the number of cited articles Maximum dissemination of your research work

Submit your manuscript at: http://papersubmission.scirp.org/

Or contact wjet@scirp.org 